\title{
17. RADIOMETRIC AGES OF BASALTIC LAVAS RECOVERED AT SITES 865, 866, AND 869¹
}

\author{
Malcolm S. Pringle ${ }^{2}$ and Robert A. Duncan ${ }^{3}$
}

\begin{abstract}
Concordant ${ }^{40} \mathrm{Ar} /{ }^{39} \mathrm{Ar}$ incremental-heating experiments yielded reliable estimates of the crystallization age of the oldest volcanic rocks sampled at each of Sites 865,866 , and 869 during Leg 143. The oldest sill near the bottom of Hole 865A on Allison Guyot is $111.1 \pm 1.3 \mathrm{Ma}$. The three oldest lavas at the base of Hole $866 \mathrm{~A}$ on Resolution Guyot average $127.6 \pm 2.1 \mathrm{Ma}$. Three basalt clasts within the thick Cenomanian volcaniclastic section at Hole 869B average $94.4 \pm 0.3 \mathrm{Ma}$. Each of these sites of volcanism had Cretaceous sources within the area defined by the modern South Pacific isotopic and thermal anomaly (SOPITA). Each of the sites also exhibited evidence of magmatic activity at least 6 m.y. later than the initial volcanic phase; such renewed activity seems to be episodic, rather than continuous, in nature. Drilling through volcaniclastic aprons remains the best (only?) way to sample the complete volcanic history of large seamounts, guyots, and oceanic plateaus.
\end{abstract}

\section{INTRODUCTION}

Geochronological control through the radiometric dating of seamount basalts provides information central to almost all of the scientific objectives of the Guyots and Atolls Drilling Program, Ocean Drilling Program (ODP) Legs 143 and 144:

1. Age of principal edifice formation,

2. Constraints on the maximum age of initial reef formation,

3. Constraints on the timing of platform drowning,

4. Constraints on the timing of relative changes in sea level and/or vertical tectonics,

5. Timing of seamount paleolatitude changes, and

6. Longevity of the mantle source of SOPITA/Dupal lavas.

During Leg 143, drilling recovered volcanic rock at three sites from two regions in the central Pacific Ocean (Fig. 1): Sites 865 and 866 at the top of Allison and Resolution guyots in the Mid-Pacific Mountains, and Site 869 on the archipelagic apron of the Wodejebato/Pikini guyot/atoll pair in the Marshall Islands. The purpose of this study is to provide reliable ${ }^{40} \mathrm{Ar} /{ }^{39} \mathrm{Ar}$ crystallization ages of these rocks. Although true volcanic basement was probably recovered only at the Resolution Guyot site, the ages of the basalts recovered at each of the three sites provide insight into the inception and duration of magmatic activity within these two important regional foci of the widespread Cretaceous volcanism found throughout the Pacific Basin.

\section{SITE SUMMARIES AND SAMPLES STUDIED}

\section{Allison Guyot, Site 865}

Site 865 is about halfway between the center and southwestern rim of Allison Guyot, in the Mid-Pacific Mountains of the central Pacific Ocean (Fig. 1). Drilling at this site penetrated nearly $140 \mathrm{~m}$ of Pleistocene to Paleocene pelagic sediments and about $700 \mathrm{~m}$ of Albian shallow-water carbonates before bottoming in about $40 \mathrm{~m}$ of interfingered clayey bioclastic limestone and three alkalic basalt sills (Sager, Winterer, Firth, et al., 1993). The bottom of the lowermost sill was not penetrated. The oldest dated sedimentary rocks, located about $110 \mathrm{~m}$ above the uppermost basalt sill, are late Aptian/early Albian in age (Arnaud-Vanneau and Sliter, this volume; Sliter, this volume).

\footnotetext{
'Winterer, E.L., Sager, W.W., Firth, J.V., and Sinton, J.M. (Eds.), 1995. Proc. ODP, Sci. Results, 143: College Station, TX (Ocean Drilling Program).

${ }^{2}$ Center for Isotope Geology, Faculty of Earth Sciences, Free University. De Boelelaan 1085, 1081 HV Amsterdam, The Netherlands.

${ }^{3}$ College of Oceanography, Oregon State University, Corvallis, OR, 97331, U.S.A.
}

The Sr-isotope stratigraphy (Jenkyns et al., this volume) also indicates a late Aptian/early Albian age for the lowermost carbonates at Site 865. According to the time scale of Harland et al. (1990), the biostratigraphy suggests a maximum age of approximately $112 \mathrm{Ma}$ for the intrusive basalts.

Only the middle sill of the three recovered at Hole 865A contained material that was considered fresh enough for ${ }^{40} \mathrm{Ar} /{ }^{39} \mathrm{Ar}$ dating. Two samples were chosen from this unit: 143-865A-93R-3, 89-92 cm, and $-94 \mathrm{R}-1,94-97 \mathrm{~cm}$. Also, several dredges taken during the site-survey cruise for this leg (the Roundabout 10 cruise of the Scripps Institution of Oceanography) recovered volcanic rocks from Allison Guyot. Winterer et al. (1993) reported a ${ }^{40} \mathrm{Ar} /{ }^{\beta 9} \mathrm{Ar}$ isochron age of $102.7 \pm$ 2.7 Ma for one of those samples (WP 72-1). We chose two additional samples from the dredged material for ${ }^{40} \mathrm{Ar} /{ }^{39} \mathrm{Ar}$ dating (WP 68-19 and WP 71-1).

\section{Resolution Guyot, Site 866}

Site 866 is about $1.5 \mathrm{~km}$ inward from the perimeter rim of Resolution Guyot, in the Mid-Pacific Mountains of the central Pacific Ocean (Fig. 1). Drilling at this site penetrated a thin veneer of winnowed and reworked pelagic sediments followed by $1600 \mathrm{~m}$ of Hauterivian to Albian shallow-water carbonates, including some Maastrichtian sediments in cavities in the platform limestone (Sager, Winterer, Firth, et al., 1993). The Hauterivian age of the basal limestone, dated by benthic foraminifers known from the Tethyan realm (Arnaud-Vanneau and Sliter, this volume), represents the oldest shallow-water carbonate yet recovered from the Pacific Basin (Sliter and Arnaud-Vanneau, 1993). The Sr-isotopic stratigraphy of the carbonate cap (Jenkyns et al., this volume) and the paleomagnetic reversal sequence seen in the lower $700 \mathrm{~m}$ of the carbonates (Tarduno et al., this volume) also indicate a Hauterivian age for the oldest carbonates recovered at Site 866.

Hole $866 \mathrm{~A}$ bottomed in a $124-\mathrm{m}$-thick basalt sequence. The sequence was originally interpreted as a series of 10 -m-thick subaerial lava flows and some possible sills separated by 0.5 -m-thick rubbly to clayey intervals (Sager, Winterer, Firth, et al., 1993). However, detailed geochemical studies (i.e., Baker et al., this volume), paleomagnetic studies (Tarduno et al., this volume), and the ${ }^{40} \mathrm{Ar} /{ }^{39} \mathrm{Ar}$ results presented below suggest that some intrusives also occur within the lava pile. Six samples were selected for ${ }^{40} \mathrm{Ar} /{ }^{39} \mathrm{Ar}$ dating. Five of the samples come from the three distinct geochemical groups related to depth in the lava sequence itself (Baker et al., this volume): (1) a relatively depleted group recovered from above $1673 \mathrm{mbsf}$, including Samples 143-866A-177B-1, 4-7 cm, and -180R-4, 129-133 cm; (2) a relatively enriched group from 1673 to $1727 \mathrm{mbsf}$, including Samples $1243-866 \mathrm{~A}-182 \mathrm{R}-2,35-38 \mathrm{~cm}$, and $-184 \mathrm{R}-1,60-62 \mathrm{~cm}$; and (3) 


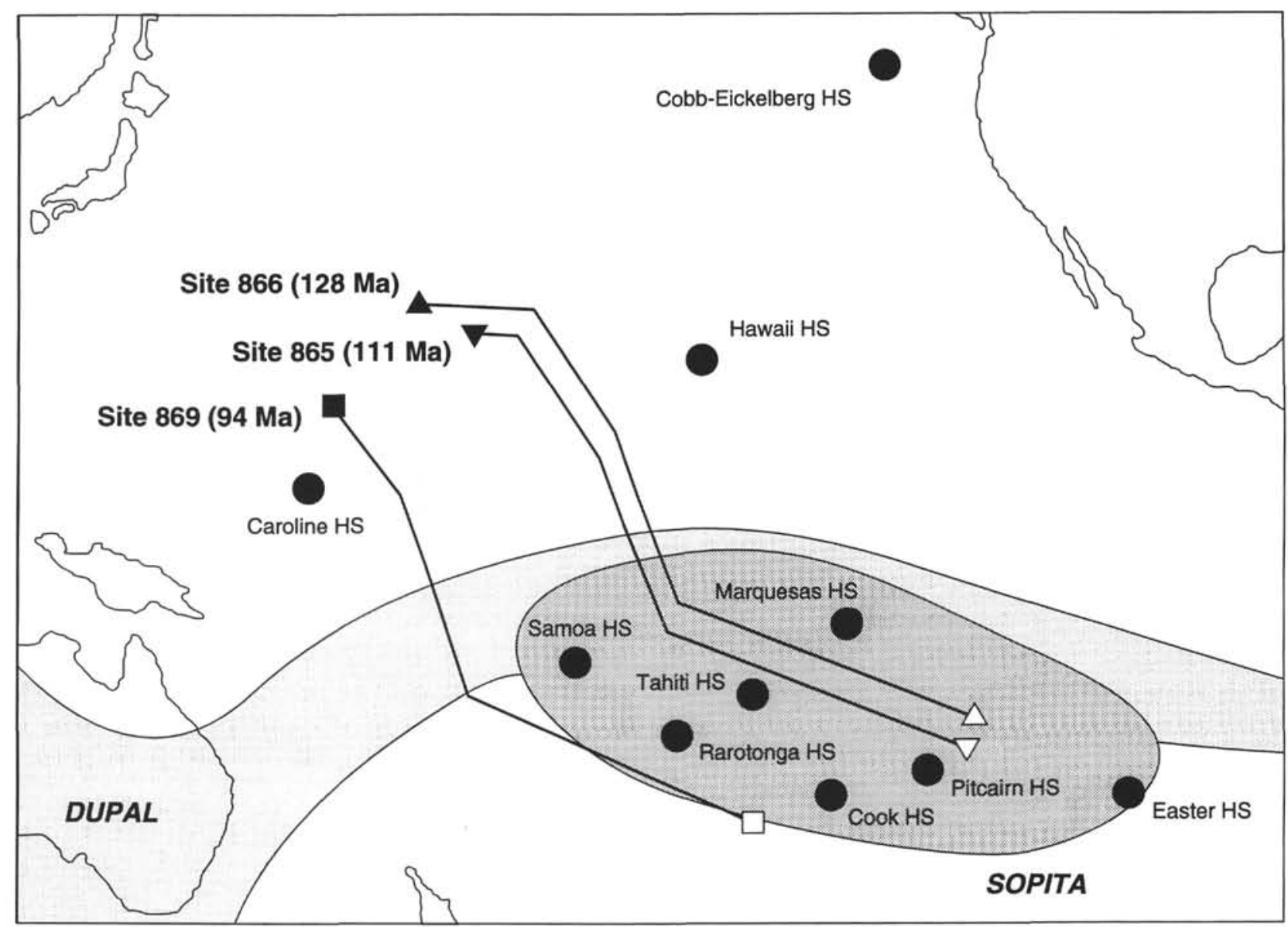

Figure 1. Present-day (solid square and triangles) and original (open square and triangles) locations of the volcanism sampled at Sites 865, 866, and 869, Leg 143. Original locations calculated by backtracking present-day locations using the weighted ages given in Table 1 and the rotation poles of Duncan and Clague (1985). Note that the volcanic source of the Hole $869 \mathrm{~B}$ apron site was actually about $75 \mathrm{~km}$ to the northeast, still within the size of the plotted square. Also shown are locations of the modern SOPITA of Staudigel et al. (1991), the DUPAL anomaly of Hart (1984), and the modern active Pacific hotspots.

a moderately enriched group from below $1727 \mathrm{~m}$, including Sample 143-866A-189R-1, 54-57 cm. The sixth sample (143-866A-174R-1, $5-8 \mathrm{~cm}$ ) comes from a section near the top of the lava sequence that consisted of mixed fragments of basalt and red clay/soil, probably best interpreted as a talus slope deposit (P. Baker, pers. comm., 1993).

\section{Wodejebato/Pikini Apron, Site 869}

Site 869 was chosen as an archipelagic apron site, $75 \mathrm{~km}$ to the southeast of the Wodejebato/Pikini guyot/atoll pair in the northern Marshall Islands. The upper part of Hole $869 \mathrm{~B}$ penetrated $208 \mathrm{~m}$ of an upper Miocene to upper Maastrichtian-lower Campanian pelagic ooze, porcellanite, and chert (Sager, Winterer, Firth, et al., 1993). The lower part of Hole 869B penetrated nearly $600 \mathrm{~m}$ of repeated sequences of Late Cretaceous volcaniclastic sandstones and breccias deposited against a background of pelagic nannofossil and radiolarian claystone. The episodic nature of the supply of the volcaniclastic sediments resulted in a distinctly nonuniform rate of deposition (Sager, Winterer, Firth, et al., 1993):

\begin{tabular}{lc}
\hline \multicolumn{1}{c}{ Age } & Thickness (m) \\
\hline & 29 \\
late Maastrichtian-early Campanian & 174 \\
Campanian & 19 \\
late Santonian & 48 \\
Turonian-Coniacian & 328 \\
late to middle-late Cenomanian & \\
\hline
\end{tabular}

In particular, a nearly 50-m-thick subunit of volcaniclastic debris and grain flows in the center of the late Cenomanian section, which contained angular to subrounded basaltic clasts as much as $8 \mathrm{~cm}$ in diameter. We chose three clasts from this subunit for dating: hawaiite, in Sample 143-869B-41R-5, 82-85 cm, for whole-rock analysis; and plagioclase-pyroxene-olivine phyric, in Samples 143-869B-41R-2, $84-86 \mathrm{~cm}$, and $-41 \mathrm{R}-4,70-73 \mathrm{~cm}$, for analysis of plagioclase separates. We have not yet tried to date any volcanic material from the Campanian section, but a datable sample would probably have to be a bulk plagioclase separate from the volcaniclastic sandstone matrix, unless individual crystals of biotite or hornblende could be found.

\section{K-Ar GEOCHRONOLOGY}

The $\mathrm{K}-\mathrm{Ar}$ clock, and especially the ${ }^{40} \mathrm{Ar} /{ }^{39} \mathrm{Ar}$ technique, has been widely used to date oceanic lavas. However, care must be used when interpreting such data because several fundamental assumptions of the technique are almost certainly violated by samples that have been altered in the submarine environment. The real power of using the ${ }^{40} \mathrm{Ar} /{ }^{39} \mathrm{Ar}$ method for deciphering the crystallization age of altered rocks is that accurate ages can be differentiated from unreliable dates using a series of internal tests for a set of apparent ages from any given sample. It may not be possible to differentiate why a particular age from a sample is unreliable, although alteration processes are clearly a contributing factor (see Pringle, 1993, for a more complete discussion). However, one can test whether the $\mathrm{K}-\mathrm{Ar}$ clock of a particular sample is too disturbed to reveal a meaningful age. 


\section{Criteria for Interpreting ${ }^{40} \mathrm{Ar} /{ }^{39} \mathrm{Ar}$ Apparent Ages}

To test whether a sample can reveal a reliable ${ }^{40} \mathrm{Ar} /{ }^{39} \mathrm{Ar}$ age, one must first generate a set of ages upon which to apply the criteria presented below. For the relatively low-potassium, moderately to highly altered samples to be analyzed here, we have found that step-heating experiments provide the most useful sets of ages. This is principally because low-temperature alteration phases tend to release their gas at lower temperatures, allowing us to examine the higher temperature gas release, presumably from higher temperature igneous phases, for a pattern representative of a concordant crystallization age.

Following Pringle (1993), we modified the conservative criteria of Lanphere and Dalrymple (1978) and Dalrymple et al. (1980) so that each criterion involves the use of a rigorous statistical test. We applied these criteria to a set of apparent ages for a given sample. We accepted that this set of apparent ages represents an accurate estimate of the crystallization age of the sample only if:

1. No age difference can be detected between any of the individual ages at the $95 \%$ confidence level. For an incremental-heating experiment, these ages should represent a well-defined, high-temperature age plateau representing three or more contiguous steps that contain at least $50 \%$ of the ${ }^{39}$ Ar released.

2. A well-defined isochron exists for the set (i.e., the $\mathrm{F}$ ratio statistic for the regression is sufficiently small at the $95 \%$ confidence level; if this ratio is exceeded, then there is more scatter about the isochron than can be explained by analytical error alone, and some additional geologic or experimental disturbance is significant).

3. The weighted mean age from Criterion 1 and the isochron age from Criterion 2 are not significantly different at the $95 \%$ confidence level.

4. $\mathrm{The}^{40} \mathrm{Ar} /{ }^{36} \mathrm{Ar}$ intercept from the isochron analysis in Criterion 2 is not significantly different from the atmospheric value of 295.5 at the $95 \%$ confidence level.

\section{Techniques}

Samples for whole-rock incremental-heating experiments were slabbed and trimmed to obtain the freshest and most holocrystalline material. These samples were either crushed to about 0.5 - to 1 - $\mathrm{mm}$ in size, hand-picked to remove vesicle and vein alteration, and cleaned in an ultrasonic bath, or prepared as 6-mm cores drilled from the freshest sections of the 1-cm-thick slabs. Plagioclase mineral separates were prepared using conventional heavy liquid and magnetic techniques, and further cleaned with cold $5 \%$ to $10 \% \mathrm{HF}$, warm $3 \mathrm{~N}$ $\mathrm{HCl}$, and, finally, distilled water in an ultrasonic bath.

The whole-rock samples, about $0.5 \mathrm{~g}$, and the plagioclase separates, about $15 \mathrm{mg}$ encapsulated in $\mathrm{Cu}$ foil packets, were sealed in fused-silica vials and irradiated for 6 to $12 \mathrm{hr}$ in the core of the Oregon State University TRIGA reactor. The efficiency of the conversion of ${ }^{39} \mathrm{~K}$ to ${ }^{39} \mathrm{Ar}$ was monitored with 27.7 Ma FCT-3 biotite or $27.92 \mathrm{Ma}$ 85G003 TCR sanidine. Corrections for interfering $\mathrm{K}$ - and $\mathrm{Ca}$-derived $\mathrm{Ar}$ isotopes are those from Dalrymple et al. (1981). ${ }^{40} \mathrm{~K}$ decay constants used were lamba $\mathrm{E}=0.581 \times 10^{-10}$ and lamda $\mathrm{B}=4.962 \times 10^{-10}$.

Argon extractions for the whole-rock samples were performed in a conventional high-vacuum glass extraction line using radiofrequency induction heating. The cleanup system consisted of a series of two titanium furnaces held at about $800^{\circ} \mathrm{C}$ to getter the reactive gases, and subsequently cooled to get hydrogen. Heating steps, each 20 min long, used fixed power levels on the RF generator, determined from previous experience to divide the Ar release into five to seven roughly equal proportions, and ranged from about $600^{\circ}$ to $1300^{\circ} \mathrm{C}$ in roughly $100^{\circ} \mathrm{C}$ increments. The argon composition of each gas increment was measured with an AEI-MS-10S mass spectrometer using computer-controlled peak switching and data acquisition. The total system blank was better than 2 to $3 \times 10^{-14}$ moles ${ }^{40} \mathrm{Ar}$ during the course of these experiments.
Argon extractions for the plagioclase separates were performed with an all-metal Staudacher-type resistance furnace and MAP-216 mass spectrometer at Stanford University, or with a defocused argon laser beam laser and MAP-215/50 mass spectrometer at the Free University, Amsterdam. Both systems use two SAES St172 getters heated to about $250^{\circ} \mathrm{C}$ for gas cleanup; the Amsterdam extraction procedure also used a glass cold finger cooled with a dry ice/alcohol slurry for some samples. The cold system blank for both systems was better than $2 \times 10^{-16}$ moles ${ }^{40} \mathrm{Ar}$ during these experiments.

Incremental-heating experiments were reduced as both age spectra and argon-isotope isochron-regressions. Errors have been reported as the standard deviation of analytical precision. Plateau ages were calculated as weighted means, where each step was weighted by the inverse of its variance. Isochron ages were calculated for both the ${ }^{40} \mathrm{Ar} /{ }^{36} \mathrm{Ar}$ vs. ${ }^{39} \mathrm{Ar} /{ }^{36} \mathrm{Ar}$ and ${ }^{36} \mathrm{Ar} /{ }^{40} \mathrm{Ar}$ vs. ${ }^{39} \mathrm{Ar} /{ }^{40} \mathrm{Ar}$ regressions using the York2 least-squares fit with correlated errors (York, 1969); Sums $/ N-2$ is the F ratio statistic for this regression. We found no significant difference between the two regressions when proper error estimates and error correlation coefficients were used (Dalrymple et al., 1988).

\section{RESULTS}

The ${ }^{40} \mathrm{Ar} /{ }^{39} \mathrm{Ar}$ age determinations for the basaltic rocks recovered at Sites 865,866 , and 869 during Leg 143 and the two dredge samples from the Allison Guyot site-survey cruise are summarized in Table 1. Age spectrum diagrams and plateau ages for each of the three sites are shown in Figures 2, 3, and 4, respectively. However, we prefer to use the isochron age, rather than the plateau age, as the best estimate of the crystallization age of each sample because it (1) combines an estimate of the degree of the internal discordance (the scatter about the isochron line) and an estimate of the analytical error in the final error estimate, and (2) makes no assumption about the composition of the initial nonradiogenic, or trapped, component. The weighted mean ages of distinguishable phases of volcanism at each site, as discussed below, are shown in boldface type in Table 1 .

\section{Allison Guyot, Site 865}

Two samples from Allison Guyot (143-865A-93R-3, 89-92 cm, from the middle sill at Site 866 and the dredged sample WP71-1) have indistinguishable, concordant incremental-heating experiments (Fig. 2 , left). The weighted mean of the two isochron ages, $110.7 \pm 1.2 \mathrm{Ma}$, is the best estimate for the age of the oldest volcanism sampled at Allison Guyot.

The second sample (143-865A-94R-1,94-97 cm, from the middle sill at the bottom of Hole $865 \mathrm{~A}$ ) has a significantly younger apparent age, $104.9 \pm 2.0 \mathrm{Ma}$. However, the Sums $/ \mathrm{N}-2$ of 4.48 from the isochron analysis for that sample (Table 1) indicates that there is significant geological error and/or some other experimental artifact in that age determination. This sample is neither petrographically nor geochemically distinct from any of the other samples from this sill. Thus, we conclude that the younger of the two dates measured from this sill has been disturbed and does not give an accurate estimate of the crystallization age of the middle sill.

Two other dated dredge samples also suggest periods of volcanism at Allison Guyot significantly younger than the oldest volcanism dated, but neither experiment meets all of the criteria used here for us to accept completely those results as reliable crystallization ages. The 102.7 \pm 2.7 Ma for WP 72-1, reported by Winterer et al. (1993), does represent $58.6 \%$ of the total ${ }^{39} \mathrm{Ar}$ released, but was calculated from only two out of six total steps. The $85.6 \pm 1.3 \mathrm{Ma}$ age reported here for WP $68-19$ (Table 1) includes $62.3 \%$ of the total ${ }^{39} \mathrm{Ar}$ released in a low temperature plateau, but the higher temperature steps are discordant, yielding significantly younger ages, but no high-temperature plateau (Fig. 2). 
Table 1. Radiometric ages of Leg 143 basalts.

\begin{tabular}{|c|c|c|c|c|c|c|c|c|c|c|c|c|c|c|}
\hline \multirow[b]{2}{*}{ Sample } & \multirow[b]{2}{*}{ Material } & \multicolumn{4}{|c|}{ Age spectrum } & & \multicolumn{8}{|c|}{ Isochron analysis } \\
\hline & & $\begin{array}{l}{ }^{39} \mathrm{Ar} \\
(\%)\end{array}$ & $\begin{array}{l}\text { Age } \\
(\mathrm{Ma})\end{array}$ & \pm & $1 \mathrm{SD}$ & & $\begin{array}{l}\text { Age } \\
(\mathrm{Ma})\end{array}$ & \pm & $1 \mathrm{SD}$ & Intercept & \pm & $1 \mathrm{SD}$ & $\frac{\text { Sums }}{N-2}$ & $N$ \\
\hline \multirow[t]{2}{*}{$\begin{array}{l}\text { Allison Guyot } \\
143-865 \mathrm{~A}-93 \mathrm{R}-3,89-92 \mathrm{~cm} \\
\text { WP 71-1 }\end{array}$} & $\begin{array}{l}\text { WR }(0.5-1.0 \mathrm{~mm}) \\
\text { WR }(0.5-1.0 \mathrm{~mm})\end{array}$ & $\begin{array}{l}96.5 \\
61.8\end{array}$ & $\begin{array}{l}111.2 \\
108.4\end{array}$ & $\begin{array}{l} \pm \\
\pm\end{array}$ & $\begin{array}{l}1.2 \\
1.6\end{array}$ & & $\begin{array}{l}111.1 \\
109.0\end{array}$ & $\begin{array}{l} \pm \\
\pm\end{array}$ & $\begin{array}{l}1.3 \\
2.7\end{array}$ & $\begin{array}{l}295.3 \\
295.3\end{array}$ & $\begin{array}{l} \pm \\
\pm\end{array}$ & $\begin{array}{r}7.3 \\
89.8\end{array}$ & $\begin{array}{l}0.15 \\
0.75\end{array}$ & $\begin{array}{l}4 \\
4\end{array}$ \\
\hline & & & & & & Wtd, age: & 110.7 & \pm & 1.2 & & & & & \\
\hline $\begin{array}{l}\text { 143-865A-94R-1, 94-97 cm } \\
\text { WP } 68-19\end{array}$ & $\begin{array}{l}\text { WR }(0.5-1.0 \mathrm{~mm}) \\
\text { WR }(0.5-1.0 \mathrm{~mm})\end{array}$ & $\begin{array}{l}67.8 \\
62.3\end{array}$ & $\begin{array}{r}104.8 \\
85.0\end{array}$ & $\begin{array}{l} \pm \\
\pm\end{array}$ & $\begin{array}{l}1.1 \\
1.2\end{array}$ & & $\begin{array}{r}104.9 \\
85.6\end{array}$ & $\begin{array}{l} \pm \\
\pm\end{array}$ & $\begin{array}{l}2.0 \\
1.3\end{array}$ & $\begin{array}{l}291.7 \\
290.7\end{array}$ & $\begin{array}{l} \pm \\
\pm\end{array}$ & $\begin{array}{r}36.8 \\
2.3\end{array}$ & $\begin{array}{l}4.48 \\
1.09\end{array}$ & $\begin{array}{l}3 \\
3\end{array}$ \\
\hline \multirow[t]{2}{*}{$\begin{array}{l}\text { Resolution Guyot } \\
\quad 143-866 \mathrm{~A}-177 \mathrm{~B}-1,4-7 \mathrm{~cm} \\
143-866 \mathrm{~A}-180 \mathrm{R}-4,129-133 \mathrm{~cm} \\
143-866 \mathrm{~A}-189 \mathrm{R}-1,54-57 \mathrm{~cm}\end{array}$} & $\begin{array}{l}\text { WR }(0.5-1.0 \mathrm{~mm}) \\
\text { WR }(0.5-1.0 \mathrm{~mm}) \\
\text { WR }(0.5-1.0 \mathrm{~mm})\end{array}$ & $\begin{array}{l}94.8 \\
83.7 \\
63.2\end{array}$ & $\begin{array}{l}122.5 \\
122.7 \\
120.1\end{array}$ & $\begin{array}{l} \pm \\
\pm \\
\pm\end{array}$ & $\begin{array}{l}1.5 \\
1.5 \\
1.5\end{array}$ & & $\begin{array}{l}121.8 \\
122.3 \\
120.5 \\
\end{array}$ & $\begin{array}{l} \pm \\
\pm \\
\pm\end{array}$ & $\begin{array}{l}2.3 \\
6.2 \\
2.5\end{array}$ & $\begin{array}{l}299.4 \\
296.9 \\
294.0\end{array}$ & $\begin{array}{l} \pm \\
\pm \\
\pm\end{array}$ & $\begin{array}{r}8.9 \\
22.9 \\
7.1\end{array}$ & $\begin{array}{l}2.00 \\
0.04 \\
0.24\end{array}$ & $\begin{array}{l}4 \\
3 \\
3\end{array}$ \\
\hline & & & & & & Wtd. age: & 121.3 & \pm & 1.6 & & & & & \\
\hline $\begin{array}{l}143-866 \mathrm{~A}-174 \mathrm{R}-1,5-8 \mathrm{~cm} \\
143-866 \mathrm{~A}-182 \mathrm{R}-2,35-38 \mathrm{~cm} \\
143-866 \mathrm{~A}-184 \mathrm{R}-1,60-62 \mathrm{~cm}\end{array}$ & $\begin{array}{l}\text { WR }(0.5-1.0 \mathrm{~mm}) \\
\text { WR }(0.5-1.0 \mathrm{~mm}) \\
\text { WR }(0.5-1.0 \mathrm{~mm})\end{array}$ & $\begin{array}{l}56.9 \\
49.9 \\
66.8\end{array}$ & $\begin{array}{l}127.1 \\
127.7 \\
126.6\end{array}$ & $\begin{array}{l} \pm \\
\pm \\
\pm\end{array}$ & $\begin{array}{l}1.5 \\
1.8 \\
1.4\end{array}$ & & $\begin{array}{l}127.7 \\
128.5 \\
119.7\end{array}$ & $\begin{array}{l} \pm \\
\pm \\
\pm\end{array}$ & $\begin{array}{c}2.4 \\
5.0 \\
12.6 \\
\end{array}$ & $\begin{array}{l}292.2 \\
289.9 \\
341.1\end{array}$ & $\begin{array}{l} \pm \\
\pm \\
\pm\end{array}$ & $\begin{array}{r}8.9 \\
34.3 \\
84.8\end{array}$ & $\begin{array}{l}0.41 \\
0.39 \\
0.45\end{array}$ & $\begin{array}{l}4 \\
4 \\
3\end{array}$ \\
\hline $143-866 \mathrm{~A}-184 \mathrm{R}-1,60-62 \mathrm{~cm}$ & & & & & & Wtd. age: & 127.6 & \pm & 2.1 & & & & & \\
\hline $\begin{array}{l}\text { Wodejebato/Pikini Apron } \\
143-869 \mathrm{~B}-41 \mathrm{R}-2,84-86 \mathrm{~cm}\end{array}$ & $\begin{array}{l}\text { Plagioclase } \\
\text { Plagioclase } \\
\text { Plagioclase } \\
\text { WR core }\end{array}$ & $\begin{array}{l}93.5 \\
93.3 \\
57.3 \\
49.4\end{array}$ & $\begin{array}{l}94.0 \\
94.6 \\
91.8 \\
96.0\end{array}$ & $\begin{array}{l} \pm \\
\pm \\
\pm \\
\pm\end{array}$ & $\begin{array}{l}0.3 \\
0.3 \\
0.3 \\
0.3\end{array}$ & & $\begin{array}{l}94.0 \\
93.9 \\
93.5 \\
96.3\end{array}$ & $\begin{array}{l} \pm \\
\pm \\
\pm \\
\pm\end{array}$ & $\begin{array}{l}0.4 \\
0.9 \\
1.0 \\
0.7\end{array}$ & $\begin{array}{l}274.3 \\
410.3 \\
220.9 \\
289.4\end{array}$ & $\begin{array}{l} \pm \\
\pm \\
\pm \\
\pm\end{array}$ & $\begin{array}{r}17.9 \\
101.6 \\
42.3 \\
10.1\end{array}$ & $\begin{array}{l}1.53 \\
1.21 \\
1.53 \\
0.34\end{array}$ & $\begin{array}{l}8 \\
9 \\
4 \\
4\end{array}$ \\
\hline $\begin{array}{l}\text { 143-869B-41R4, 70-73 cm } \\
143-869 \mathrm{~B}-41 \mathrm{R}-5,82-85 \mathrm{~cm}\end{array}$ & & & & & & Wtd. age: & 94.4 & \pm & 0.3 & & & & & \\
\hline
\end{tabular}

Notes: Site 869 ages reported relative to $85 \mathrm{G} 003$ TCR sanidine at $27.92 \mathrm{Ma}$; all other ages relative to FCT- 3 biotite at $27.7 \mathrm{Ma}$. SD = standard deviation, $N=$ number of samples, WR $=$ whole rock, Wtd. age $=$ weighted mean age.
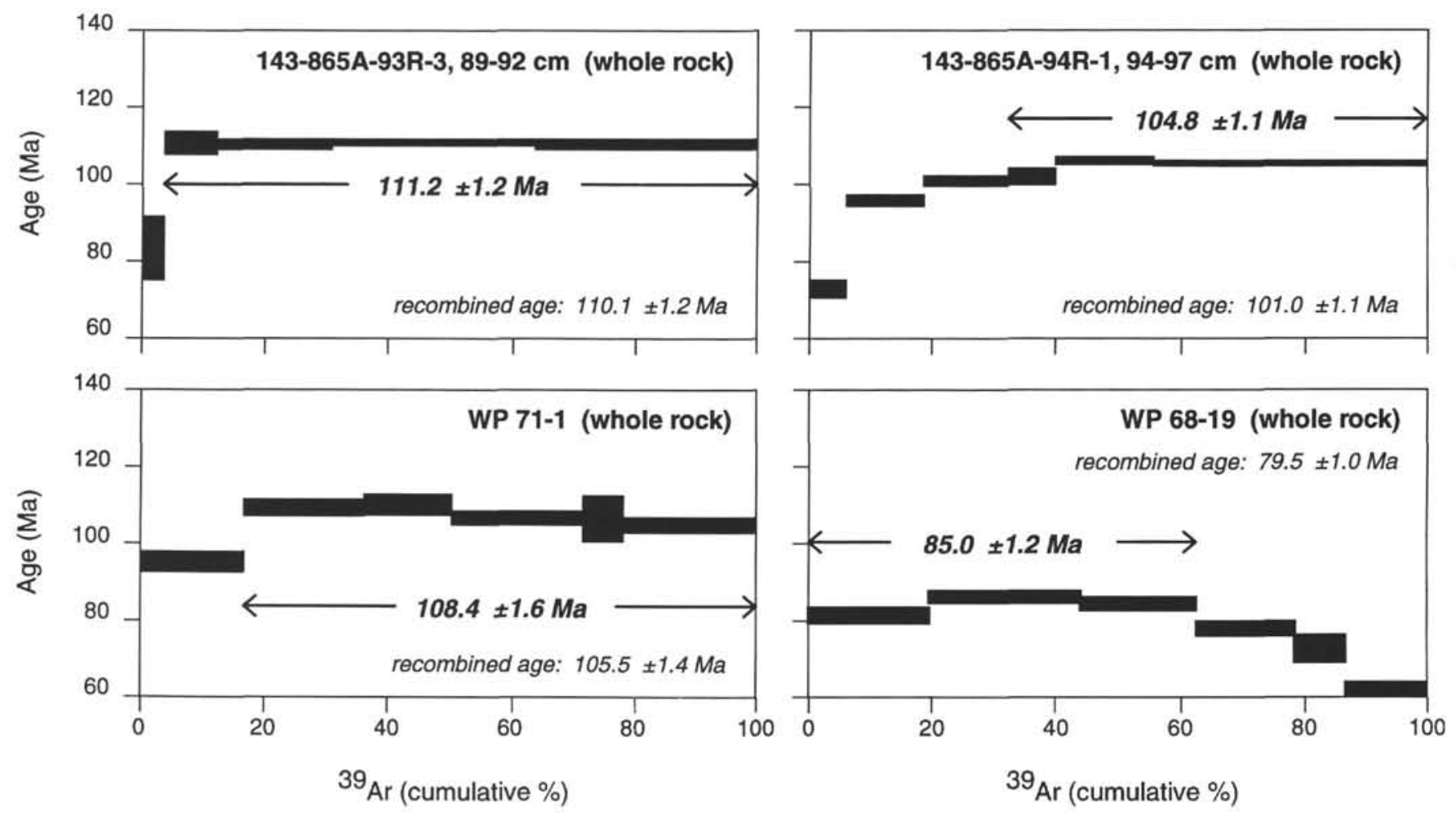

Figure 2. Age spectra of incremental-heating experiments on whole-rock samples from Allison Guyot. Individual step ages are drawn \pm 1 standard deviation of the apparent age. Samples on left date the oldest volcanism sampled at Allison Guyot, those on the right suggest that some volcanism may have continued for approximately $30 \mathrm{~m} . \mathrm{y}$. 

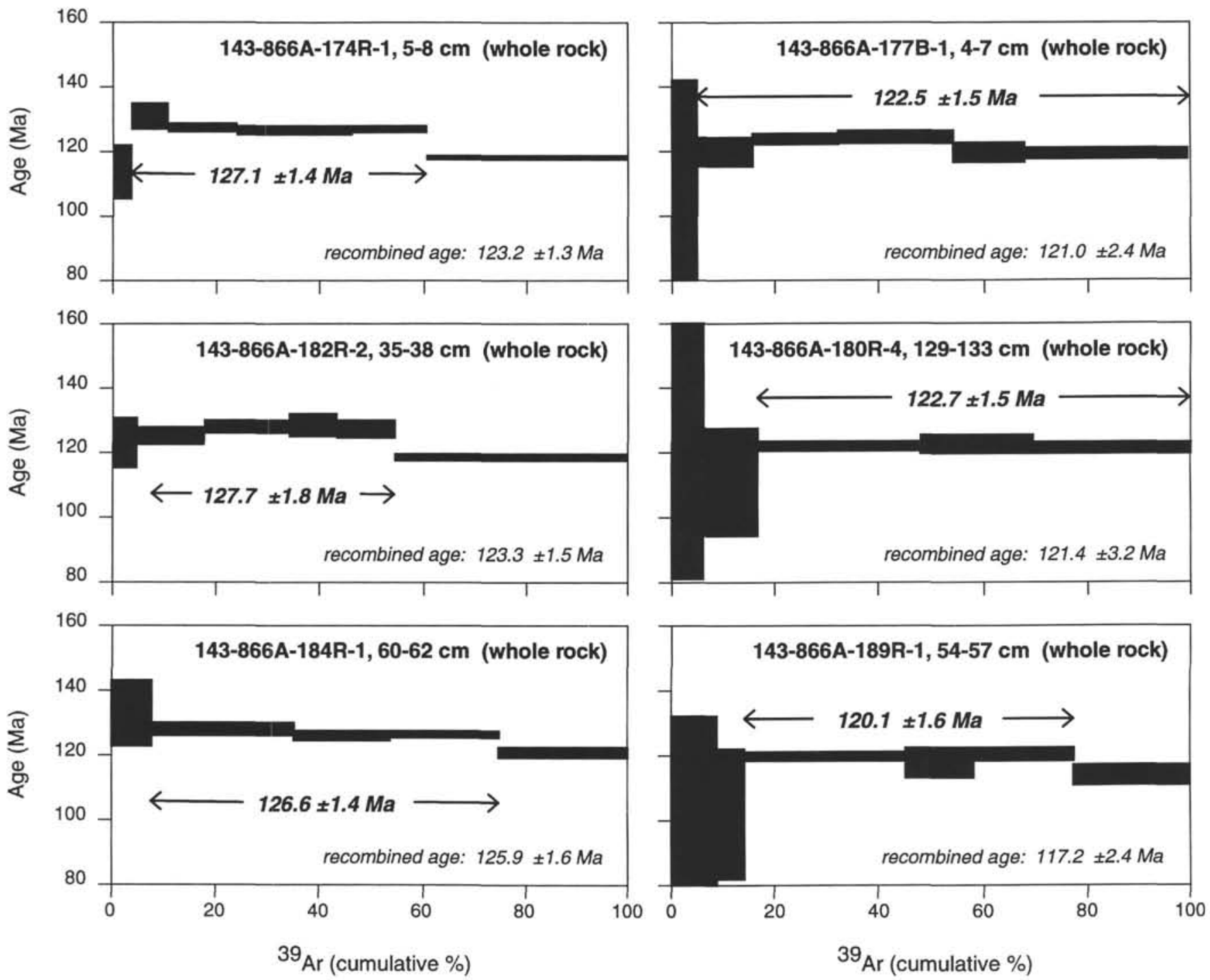

Figure 3. Age spectra of incremental-heating experiments on whole-rock samples from Resolution Guyot, Hole $866 \mathrm{~A}$. Individual step ages are drawn \pm 1 standard deviation of the apparent age.

\section{Resolution Guyot, Site 866}

The six samples dated from the volcanic basement of Resolution Guyot fall into two distinguishable groups (Table 1). The sample from the upper talus slope deposit and the two samples from the enriched lavas represent the oldest volcanism dated at Resolution Guyot (Fig. 3, left). The weighted mean age of these three experiments is the best estimate for the age of volcanic basement at Hole 866A, 127.6 $\pm 2.1 \mathrm{Ma}$.

The other three samples dated from Hole 866A, the two from the upper, depleted geochemical group and the single sample from the lower, mildly enriched group, are analytically indistinguishable (Table 1; Fig. 3, right). The weighted mean age of those three samples is $121.3 \pm 1.6 \mathrm{Ma}$. This suggests that these units were sills intruded approximately $6 \mathrm{~m} . \mathrm{y}$. after the initial formation of the volcanic basement at Hole 866A. We note that Baker et al. (this volume) was able to relate these two later magma groups by crystal fractionation, but that neither of these groups could be related by fractionation to the older, more enriched lavas.

\section{Wodejebato/Pikini Apron, Site 869}

All of the incremental-heating experiments of the samples from the volcaniclastic breccia sampled at Hole 869B were concordant. The weighted age of the four experiments is $94.4 \pm 0.3 \mathrm{Ma}$ (Table 1 and Fig. 4). Strictly speaking, one of the plagioclase experiments and the whole-rock experiment are significantly different at the $95 \%$ confidence level. Thus, it is most correct to consider the ages as two distinct volcanic events: the plagioclase-phyric clasts, with a weighted age of $93.9 \pm 0.3 \mathrm{Ma}$, and the hawaiite, at $96.3 \pm 0.7 \mathrm{Ma}$.

\section{DISCUSSION}

Concordant ${ }^{40} \mathrm{Ar}{ }^{39} \mathrm{Ar}$ incremental-heating experiments yielded reliable estimates of the crystallization age of the oldest volcanic rocks sampled at Sites 865,866 , and 869 . Using these ages (Table 1) and stage rotation poles describing Pacific/hotspot motion, such as those of Duncan and Clague (1985), we can determine the original 

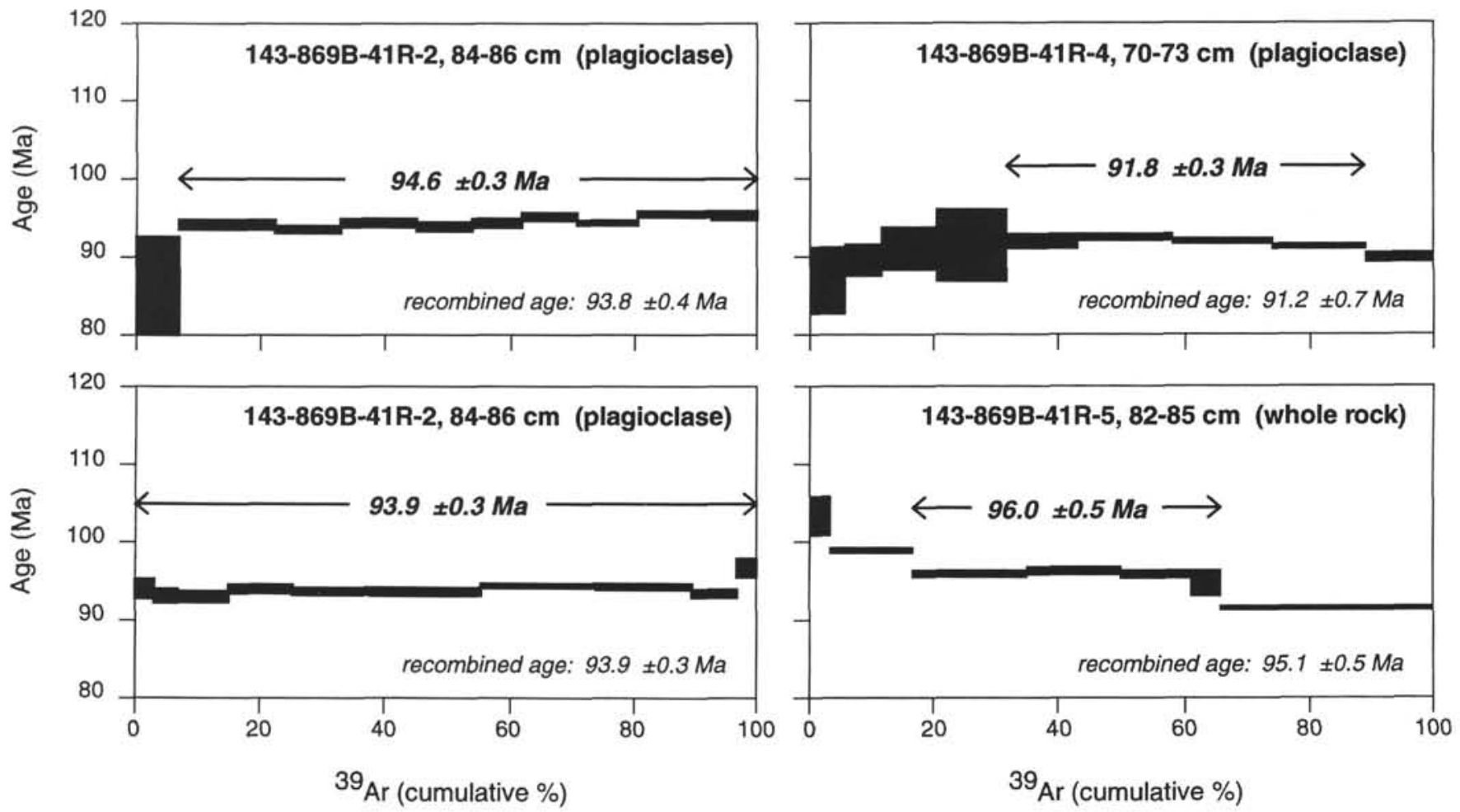

Figure 4. Age spectra of incremental-heating experiments on whole-rock samples and plagioclase separates from Hole 869B. Individual step ages are drawn \pm 1 standard deviation of the apparent age.

location of the volcanoes when they formed (Fig. 1). Each of these sites had a volcanic source within the limits of Staudigel et al.'s (1991) modern SOPITA. Magmatic activity at Sites 865 and 866, in the Mid-Pacific Mountains, had an origin in the eastern SOPITA, near Pitcairn and Easter islands. The source of the volcanic clasts sampled at Site 869, in the Marshall Islands, had an origin near the southern limit of the modern SOPITA, south of the Austral-Cook Islands.

The 127.6 $\pm 2.1 \mathrm{Ma}$ age of the basement lavas at Site 866 (Resolution Guyot) may also help to define critical parts of the ill-defined Early Cretaceous geological reversal time scale (GRTS). Given the radiometric age of the basement lavas, and a Hauterivian/Barremian boundary age of 131.8 Ma within Chron M7N (Harland et al., 1990), the age of the overlying sediments at Site 866 should be Barremian, with a magnetic signature younger than Chron M4. This does not agree with the Hauterivian age of the oldest carbonates (ArnaudVanneau and Sliter, this volume; Jenkyns et al., this volume) and the identification of at least Chron M5R in the lowermost carbonates and basalts (Tarduno et al., this volume). However, a new version of the numerical time scale (Gradstein et al., in press), although still having the Barremian/Hauterivian boundary near Chron M7N, suggests a revised age of 126.5 Ma for the boundary. Also, Cecca et al. (in press), based on new ammonite control on some of the well-studied Italian sections, move the Barremian/Hauterivian boundary to within Chron M4N. All of these revisions tend to move the $127.6 \mathrm{Ma}$ age of the oldest basalts at Site 866 into the Hauterivian and encourage us to work on improving the precision of radiometric age for the basement lavas at Site 866.

Each of the sites of Cretaceous volcanism studied here also has evidence for magmatic activity significantly younger than the oldest rocks dated there. Resolution Guyot (Site 866) has several apparent sills about $6 \mathrm{~m}$.y. younger than the basement lavas. Allison Guyot (Roundabout 10 samples), even considering that the apparent ages determined on the dredged material must be treated with some caution, seems to have had volcanic activity up to $30 \mathrm{~m}$.y. after the oldest sills. Recent SeaBeam and seismic studies also indicate post-platform volcanic activity on the eastern portion of Allison Guyot, with a cluster of virtually uneroded volcanic cones cutting through the platform carbonates, significantly different from the much smoother relief on the volcanic basement beneath the platform limestone cover elsewhere on the guyot (J. Winterer, pers. comm., 1994). The volcaniclastic section at Site 869 shows a significant volcanic resurgence during the Campanian, 10 to 15 m.y. after the initial Cenomanian deposits. The section at Site 869 also suggests that this later volcanism is more episodic, rather than continuous, in nature. This episodic, continued volcanism seems to be characteristic of the volcanoes of the central and western Pacific (see also Lincoln et al., 1993) and must be taken into consideration when attempting to decipher the magmatic history of these volcanoes, especially with a limited sample set, such as a few dredge samples.

In particular, the lessons learned by comparing the results of drilling on the archipelago apron Site 869 with those from drilling on the top of Wodejebato Guyot during Leg 144 (Sites 871 through 877; Premoli Silva, Haggerty, Rack, et al., 1993) are sobering when we consider deciphering the volcanic history of other large Cretaceous Pacific volcanic edifices from limited sample sets. Pringle et al. (1993) concluded that all of the recovered lavas from the top of Wodejebato Guyot, including samples dredged from the northeast rift zone, were most probably erupted during magnetic Chron $33 \mathrm{R}$, about 84 to $79 \mathrm{Ma}$. It is reasonable to propose that this Campanian volcanism provided the source of the volcanogenic sands seen in the Campanian section of Site 869 . However, this volcanism is significantly younger than the reworked Cenomanian nannofossils found at Site 877 on the top of Wodejebato Guyot (Premoli Silva, Haggerty, Rack, et al., 1993), Cenomanian to Albian rudists dredged from the southwestern flanks of the guyot (Lincoln et al., 1993), and the 96- to 94-Ma ages of the basaltic clasts from the thick Cenomanian volcaniclastic deposits of Site 869 reported herein. Thus, there must have been a Cenomanian or older edifice at Wodejebato Guyot, even 
though it was not sampled by the five summit sites drilled during Leg 144. The only actual samples that we have of this Cenomanian or older volcanism are from the volcaniclastic deposits drilled in the archipelago apron site, $75 \mathrm{~km}$ to the southwest of Wodejebato Guyot. Therefore, we conclude that drilling through volcaniclastic apron sites remains the best (only?) way to sample the complete volcanic history of large volcanic edifices in the submarine environment, such as large seamounts, guyots, and oceanic plateaus.

\section{ACKNOWLEDGMENTS}

We thank P. Baker and P. Castillo for helping to select the Site 865 and 866 samples, P. Janey and P. Castillo for helping to select the Site 869 samples, and J. Natland for helping to select the Roundabout 10 samples. The staff of the Oregon State University TRIGA reactor facility provided all of the neutrons necessary for the ${ }^{40} \mathrm{Ar} /{ }^{39} \mathrm{Ar}$ ages reported here. This research was partially supported by JOI/USSAC post-cruise science grant \#143-20759B to R. Duncan at Oregon State University, JOI/USSAC post-cruise science grant \#143-20759B to M. Pringle and M. McWilliams at Stanford University, and an NSF International Postdoctoral Fellowship to M. Pringle at the Free University, Amsterdam. We also thank Mike McWilliams for open access to the ${ }^{40} \mathrm{Ar} /{ }^{39} \mathrm{Ar}$ facility at Stanford University that he has provided over the last several years. Tom Fleming and Brent Dalrymple provided careful and constructive reviews of the manuscript.

\section{REFERENCES}

Cecca, F., Pallini, G., Erba, E., Premoli Silva, I., and Coccioni, R., in press. Hauterivian-Barremian chronostratigraphy based on ammonites, nannofossils, planktonic foraminifera, and magnetic chrons from the Mediterranean domain. Cretaceous Res.

Dalrymple, G.B., Alexander, E.C., Lanphere, M.A., and Kraker, G.P., 1981. Irradiation of Samples for ${ }^{40} \mathrm{Ar}{ }^{\beta 9} \mathrm{Ar}$ Dating Using the Geological Survey TRIGA Reactor. Geol. Surv. Prof. Pap. U.S., 1176.

Dalrymple, G.B., Lanphere, M.A., and Clague, D.A., 1980. Conventional and ${ }^{40} \mathrm{Ar} /{ }^{39} \mathrm{Ar} \mathrm{K}$-Ar ages of volcanic rocks from Ojin (Site 430), Nintoku (Site 432) and Suiko (Site 433) seamounts and the chronology of volcanic propagation along the Hawaiian-Emperor Chain. In Jackson, E.D., Koizumi, I., et al., Init. Repts. DSDP, 55: Washington (U.S. Govt. Printing Office), 659-676.

Dalrymple, G.B., Lanphere, M.A., and Pringle, M.S., 1988. Correlation diagrams in ${ }^{40} \mathrm{Ar}{ }^{39} \mathrm{Ar}$ dating: is there a correct choice? Geophys. Res. Lett., 15:589-591.

Duncan, R.A., and Clague, D.A., 1985. Pacific plate motion recorded by linear volcanic chains. In Nairn, A.E.M., Stehli, F.G., and Uyeda, S. (Eds.), The Ocean Basins and Margins (Vol. 7A): The Pacific Ocean: New York (Plenum), 89-121.

Gradstein, F.M., Huang, Z., Agterberg, F.P., Ogg, J.G., and Hardenbol, J., in press. A Mesozoic time scale. J. Geophys. Res.
Harland, W.B., Armstrong, R.L., Cox, A.V., Craig, L.E., Smith, A.G., and Smith, D.G., 1990. A Geologic Time Scale 1989: Cambridge (Cambridge Univ. Press).

Hart, S.R., 1984. A large-scale isotope anomaly in the Southern Hemisphere mantle. Nature, 309:753-757.

Lanphere, M.A., and Dalrymple, G.B., 1978. The use of ${ }^{40} \mathrm{Ar} /{ }^{39} \mathrm{Ar}$ data in evaluation of disturbed K-Ar systems. In Zartman, R.E. (Ed.), Short Papers of the Fourth International Conference, Geochronology, Isotope Geology. Open-File Rep.-U.S. Geol. Surv., 78-701:241-243.

Lincoln, J.M., Pringle, M.S., and Premoli-Silva, I., 1993. Early and Late Cretaceous volcanism and reef-building in the Marshall Islands. In Pringle, M.S., Sager, W.W., Sliter, W.V., and Stein, S. (Eds.), The Mesozoic Pacific: Geology, Tectonics, and Volcanism. Geophys. Monogr., Am. Geophys. Union, 77:279-305.

Premoli Silva, I., Haggerty, J., Rack, F., et al., 1993. Proc. ODP, Init. Repts., 144: College Station, TX (Ocean Drilling Program).

Pringle, M.S., 1992. Radiometric ages of basaltic basement recovered at Sites 800, 801, and 802, Leg 129, western Pacific Ocean. In Larson, R.L., Lancelot, Y., et al., Proc. ODP, Sci. Results, 129: College Station, TX (Ocean Drilling Program), 389-404.

, 1993. Age progressive volcanism in the Musicians Seamounts: a test of the hot-spot hypothesis for the Late Cretaceous Pacific. In Pringle, M.S., Sager, W.W., Sliter, W.V., and Stein, S. (Eds.), The Mesozoic Pacific; Geology, Tectonics, and Volcanism. Geophys. Monogr., Am. Geophys. Union, 77:187-215.

Pringle, M.S., Staudigel, H., Duncan, R.A., Christie, D.M., and ODP Leg 143 and 144 Scientific Staffs, $1993 .{ }^{40} \mathrm{Ar} /{ }^{39} \mathrm{Ar}$ ages of basement lavas at Resolution, MIT, and Wodejebato Guyots compared with magneto- and bio- stratigraphic results from ODP Legs 143/144. Eos, 74:354.

Sager, W.W., Winterer, E.L., Firth, J.V., et al., 1993. Proc. ODP, Init. Repts., 143: College Station, TX (Ocean Drilling Program).

Sliter, W.V., and Arnaud-Vanneau, A., 1993. Resolution Guyot: the oldest Pacific island. Eos, 74:354.

Staudigel, H., Park, K.-H., Pringle, M., Rubenstone, J.L., Smith, W.H.F., and Zindler, A., 1991. The longevity of the south Pacific isotopic and thermal anomaly. Earth Planet. Sci. Lett., 102:24 44.

Winterer, E.L., Natland, J.H., van Waasbergen, R.J., Duncan, R.A., McNutt, M.K., Wolfe, C.J., Premoli Silva, I., Sager, W.W., and Sliter, W.V., 1993. Cretaceous guyots in the Northwest Pacific: an overview of their geology and geophysics. In Pringle, M.S., Sager, W.W., Sliter, W.V., and Stein, S. (Eds.), The Mesozoic Pacific: Geology, Tectonics, and Volcanism. Geophys. Monogr., Am. Geophys. Union, 77:307-334.

York, D., 1969. Least-squares fitting of a straight line with correlated errors. Earth Planet. Sci. Lett., 5:320-324.

-Abbreviations for names of organizations and publications in ODP reference lists follow the style given in Chemical Abstracts Service Source Index (published by American Chemical Society).

Date of initial receipt: 7 December 1993

Date of acceptance: 6 July 1994

Ms 143SR-218 